\title{
The different roles of innate immune receptors in inflammation and carcinogenesis between races
}

\author{
Natsu Yamaguchi ${ }^{1}$, Yoshimi Suzuki², M. H. Mahbub', Hidekazu Takahashi', Ryosuke Hase', Yasutaka Ishimaru', \\ Hiroshi Sunagawa', Rie Watanabe ${ }^{1}$, Yoshinobu Eishi ${ }^{2}$ and Tsuyoshi Tanabe ${ }^{1^{*}}$
}

\begin{abstract}
Innate immune factors exert widespread effects on cytokine secretion, cell survival, autophagy, and apoptosis. Nucleotide-binding and oligomerization domain-like receptors (NLRs) are members of the innate immune system in the cytosol that sense pathogens, endogenous danger molecules such as uric acid, and pollutants. Nucleotidebinding oligomerization domain-containing protein 1 and 2 (NOD1 and NOD2) are components of NLR family, and ligands of these factors are $Y$-D-glutamyl-meso-diaminopimelic acid (iE-DAP) and muramyl dipeptide (MDP), respectively. Upon recognition of ligands, NOD1 and NOD2 induce the production of inflammatory cytokines and transcription factors including interleukin-6 (IL-6) and nuclear factor-KB (NF-KB). We examined the function of NOD1 and NOD2 in innate immunity, with a focus on their differing roles in disease pathogenesis between Japanese and Caucasian populations. Susceptibility to several immune-related diseases, including Crohn's disease, colorectal and breast cancers, and graft-versus-host-disease (GVHD) showed a correlation with genetic variants of NOD2 in Caucasian, but not in Japanese, populations. This difference may be primarily due to the fact that three major NOD2 SNPs (R702W, G908R, L1007insC) prevalent in Caucasians are rare or absent in Japanese populations. Because NLR has diverse effects on immune function, it is possible that many as yet uncharacterized immune-related diseases will also show different susceptibilities between races due to the different ratio of genetic variants in innate immune genes.
\end{abstract}

Keywords: TLR, NOD, Crohn's disease, Sarcoidosis

\section{Background}

Two types of immune mechanisms, innate system and adaptive system, are used to eliminate the invading pathogens, endogenous danger molecules, and pollutants. As a first step of immune system, innate immune responses are mediated by a set of non-clonal, germline-encoded pattern-recognition receptors (PRRs) that sense conserved pathogen-associated molecular patterns (PAMPs) in pathogens and danger-associated molecular patterns (DAMPs). PAMPs include flagellin, single RNA, unmethylated CpG DNA, and lipopolysaccharides. DAMPs consist of endogenous factors such as fatty

\footnotetext{
* Correspondence: tanabe@yamaguchi-u.ac.jp

${ }^{1}$ Department of Public Health and Preventive Medicine, Graduate School of Medicine, Yamaguchi University, 1-1-1 Minami-Kogushi, Ube, Yamaguchi 755-8505, Japan

Full list of author information is available at the end of the article
}

acids, heat shock proteins (HSP), and uric acid. Recent studies revealed that PRPs also recognize pollutants including asbestos [1] and PM2.5 [2]. Various PRRs exist in the extracellular space, integrated in cellular membranes, and in the cytosol. The toll-like receptors (TLRs) were first identified as genes that determine body axis. They represent a class of membrane-bound PRRs that respond to PAMPs and DAMPs at the cell surface and within endosomes [3] (Fig. 1). The nucleotide-binding oligomerization domain (NOD)-like receptor (NLR) family consists of cytoplasmic PRRs that play a pivotal role in sensing PAMPs and DAMPs in the cytosol [4]. The NLR family consists of more than 20 cytosolic proteins that are characterized by the presence of a conserved tripartite domain structure: C-terminal leucine-rich repeats (LRRs) that are involved in sensing of ligands, a central NOD domain, and an N-terminal 


\section{TLRs}

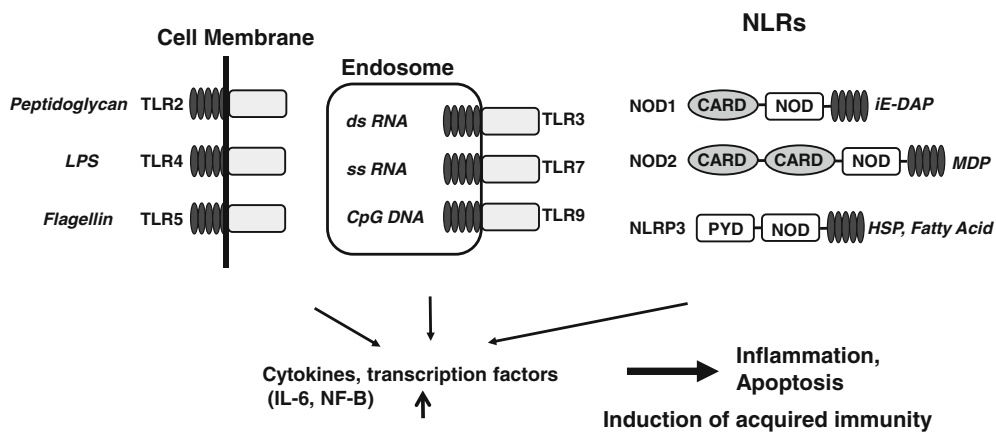

Fig. 1 Innate immune receptors, NLRs and TLRs. The main members of the innate immune system are NLRs (membrane binding) and TLRs (in the cytosol). NLRs and TLRs sense intracellular and extracellular PAMPs, respectively. The subsequent activation of inflammatory cytokines including IL-6 and NF-KB results in the inflammation, apoptosis, and autophagy. These pathways are involved in the induction of acquired immunity

effector-binding domain, such as the Pyrin domain (PYD) and the caspase recruitment domain (CARD) [4].

\section{NOD1 and NOD2}

NOD1 and NOD2 are members of the NLR family with an N-terminal CARD domain (Fig. 2). In early studies, NOD1 and NOD2 were found to induce nuclear factor$\kappa \mathrm{B}(\mathrm{NF}-\mathrm{\kappa} \mathrm{B})$ activation when overexpressed in mammalian cells and to eliminate pathogens independently of TLRs [5]. The ligand for NOD1 is $\gamma$-D-glutamyl-mesodiaminopimelic acid (iE-DAP) found in many gramnegative and certain gram-positive bacteria [6]. As ligand, NOD2 recognizes muramyl dipeptide (MDP), a component of peptidoglycan that is present in both gram-positive and gram-negative bacteria [7]. Nod1 and Nod2 undergo conformational changes upon recognition of ligands, resulting in self-oligomerization via the central NOD domain and binding to receptor-interacting protein (RIP)-like interacting caspase-like apoptosis regulatory protein kinase (RICK, RIP2), a serine threonine kinase that leads to NF- $\mathrm{BB}$ activation [8]. The tissue distribution patterns of NOD1 and NOD2 are quite different. Expression pattern of Nod1 is ubiquitous in various tissues and Nod2 is restrictedly expressed in the Paneth cells of the small intestine and monocytes [4]. In vivo studies have revealed that NOD1 ligands simulate chemokine production and recruitment of neutrophils [9] and contribute to adaptive immune responses.

\section{Crohn's disease}

Crohn's disease (CD) is characterized by recurring inflammation in the gastrointestinal tract. We reported the

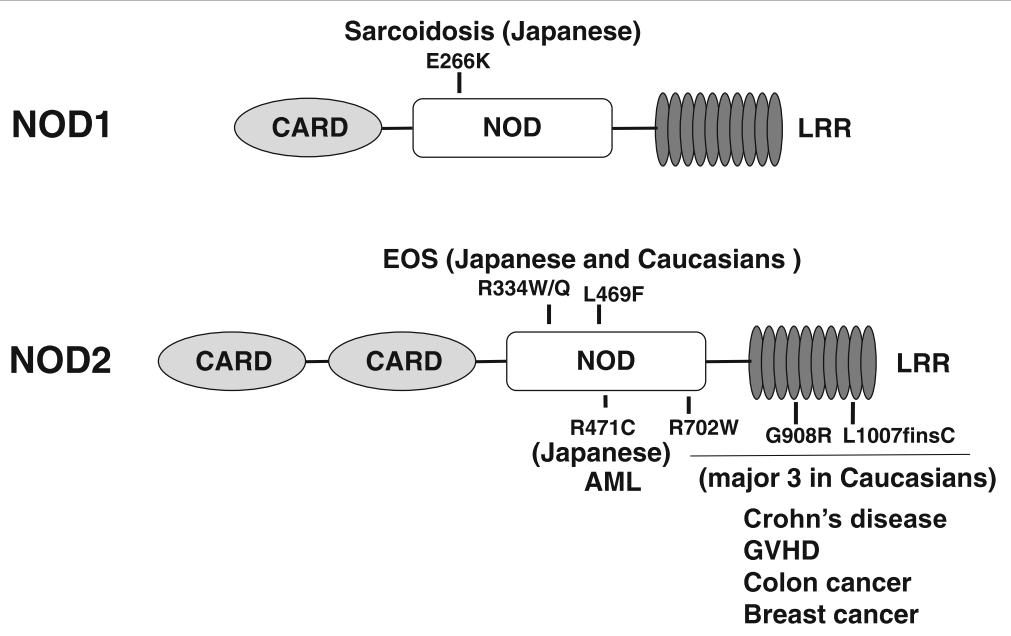

Fig. 2 Mutations in NLR that cause immune-related diseases. NOD1 variant E266K associated with sarcoidosis was found in Japanese population. Three mutations in NOD domain of NOD2 (R334W, R334Q, and L469F) exist both in Blau syndrome in Caucasians and EOS in Japanese cohort. NOD2 SNPs near or within the LRRs of Nod2 (R702W, G908R, L1007insC) are associated with the development of CD in Caucasians that does not exist in Japanese cohort 
association between genetic polymorphisms of NOD2 and susceptibility to CD in Caucasians [10] (Fig. 2). The genetic variants of NOD2 found in about $10 \%$ of CD patients, including three common mutations that involve amino acid residues in NOD domain (R702W) or within LRRs (G908R and L1007insC) of Nod2, showed association with the development of CD. Ethnic differences in the genetic susceptibility to $C D$ have been reported between Caucasian and Asian populations. Several studies revealed that none of the three common NOD2 variants that have been associated with $\mathrm{CD}$ in Caucasians are present in Japanese [11], Chinese [12], and Korean [13] $\mathrm{CD}$ patients. Also, a systemic genomic screening of the entire coding region of NOD2 in a Japanese CD population showed no common genetic variants [14]. These results apparently indicate that the NOD2 gene is not a major contributor to $\mathrm{CD}$ susceptibility in Asian population. Our functional analysis showed that $\mathrm{CD}$-associated mutations lead to the reduction (R702W, G908R) or loss (L1007insC) of NF-kB activation upon MDP stimulation, compared with the wild-type NOD2 [4].

The plausible mechanism to explain the association between mutants of NOD2 and susceptibility to CD was estimated by constructing NOD2-deficient mice [15]. The mice showed that the NOD2 protein is a key regulator of immunity within the intestine. These animals failed to recognize bacterial muramyl dipeptide and were susceptible to bacterial infections through the oral route but not via the peritoneal or intravenous route. Further, it turned out that NOD2 was necessary to express defensins, a subgroup of intestinal anti-microbial peptides. The estimated hypothesis was that the dysfunction of NOD2 may lead to facilitated entry of bacteria into epithelial cells through defective regulation of defensin expression, leading to an abnormal inflammatory response to uncleared bacteria.

\section{Blau syndrome (BS) and early-onset sarcoidosis (EOS)}

BS is a rare autosomal dominant disease characterized by early-onset granulomatous inflammation including uveitis, arthritis, and dermatitis with camptodactyly [16]. Because BS susceptibility locus has been identified at $16 \mathrm{p} 12$ to which coincides with that of NOD2, genetic screening of NOD2 were performed in families with BS [17]. BS families shared three missense mutations (R334Q, L469F, and R334W) in NOD2 (Fig. 2). We analyzed the function of these mutations and found that all of them augmented NOD2 basal activity, even in the absence of the ligand MDP [18], and further enhanced NOD2 activity by addition of MDP. Thus, the genetic variants in NOD2 associated with BS function as hyperresponsive mutations, which is consistent with the dominant mode of inheritance of the granulomatous disease.
EOS is a systemic granulomatous syndrome sharing the distinct triad of skin, joint, and eye inflammation with $\mathrm{BS}$ and is progressive and causes severe complications, such as destructive arthropathy and blindness. Systemic analysis of NOD2 genes of the EOS cases in Japanese population also showed the same mutations as in BS [19]. Thus, EOS shares a common genetic etiology of NOD2 with BS.

\section{Sarcoidosis}

Sarcoidosis, a chronic systemic granulomatous disease of unknown cause, may result from the exposure of genetically susceptible subjects to a specific environmental agent(s). The only bacterium to be isolated from sarcoid lesions to date is Propionibacterium acnes (P. acnes) [20]. We found that both NOD1 and NOD2 proteins recognize intracellular $P$. acnes. Systematic search for NOD1 gene polymorphisms in Japanese sarcoidosis patients identified significant elevation of G796A in sarcoidosis patients (Fig. 2). Genetic screening of the NOD2 gene in sarcoidosis revealed no common mutations in Japanese and Caucasian subjects [21, 22]. Our functional analysis revealed that the NOD1 G796A was associated with lower expression in protein level leading to reduced NF- $\mathrm{KB}$ activation in response to intracellular $P$. acnes [23]. These results indicate that impaired recognition of intracellular $P$. acnes through NOD1 variant causes the susceptibility to sarcoidosis in the Japanese population.

\section{Malignant diseases}

Mutations in the NOD2 gene associated with Crohn's disease have also been associated with an increased risk for the development of different types of cancer (Helicobacter pylori-induced MALT lymphoma, colonic adenocarcinoma, and breast and lung cancer) in Caucasians [24-26]. In Japanese populations, we revealed that a NOD2 SNP in the NOD domain (R471C) has been associated with acute myeloid leukemia (AML) but not with acute lymphoblastic leukemia [27] (Fig. 2). This difference may be explained by the results of recent studies that revealed an important role of NOD2 in the differentiation of bone marrow $\mathrm{CD} 34^{+}$hematopoietic cells, by mediating the induction of cytokines indispensable for cell differentiation toward the myeloid lineage [28]. It is possible that the NOD2 variant causes abnormal cell differentiation by altering cytokine production, thus leading to the elevated incidence of AML. There are several possible mechanisms that may account for the contribution of NOD2 to the risk of malignant diseases. Impairment of the innate immune system by NOD2 variants may induce chronic activation of alternate recognition receptors, such as the TLR, which can also lead to NF- $k B$ activation and pro-inflammatory cytokine release, 
possibly provoking the inflammation-dysplasiacarcinoma sequence [29]. In addition to its role in the non-specific innate immune system, NOD2 may generate signals for the adaptive immune response, through cytokine release, leading to the activation of dendritic cells and the promotion of T cell differentiation. NOD2 variants may impair the adaptive immune system in evoking anti-tumor immunity [30].

\section{Graft-versus-host disease (GVHD)}

Several recent studies in Caucasian patients have described a significant correlation between the severity of acute GVHD and the presence of three NOD2 SNPs: R702W, G908R, and L1007insC. Holler et al. reported an increased incidence and severity of acute GVHD associated with the presence of NOD2 SNPs in two separate patient cohorts $[31,32]$. In contrast, Granell et al. demonstrated that in a $\mathrm{T}$ cell-depleted setting, these SNPs had no effect on acute GVHD [33]. In our analysis in a severe GVHD Japanese patient group, no genetic alteration of NOD2, including the three major SNPs seen in Caucasians, were found [26]. Previous studies have shown that Japanese and Swedish patient populations have a lower probability of acute GVHD [34]. No dysfunctional NOD2 variants were found in the severe acute GVHD group that may explain the differences in the occurrence of acute GVHD among different ethnic populations.

\section{Conclusions}

We discussed the physiology of NLR-related diseases and ethnic differences between Caucasians and Japanese. The three mutations of NOD2 cause increased susceptibility to Crohn's disease and several other malignant diseases, including colorectal and breast cancers in Caucasians, but the Japanese population lacks the NOD2 mutations. Because NLR exerts widespread effects on cytokine secretion, cell survival, autophagy, and apoptosis, it is possible that many as yet uncharacterized diseases will also show differences in susceptibility between races.

\footnotetext{
Abbreviations

AML: Acute myeloid leukemia; BS: Blau syndrome; CARD: Caspase recruitment domain; CD: Crohn's disease; DAMPs: Danger-associated molecular patterns; EOS: Early-onset sarcoidosis; GVHD: Graft-versus-host-disease; iE-DAP: Y-D-glutamyl-meso-diaminopimelic acid; IL-6: Interleukin-6; MDP: Muramyl dipeptide; NF-kB: Nuclear factor-KB; NLRs: Nucleotide-binding and oligomerization domain-like receptors; NOD1 and NOD2: Nucleotide-binding oligomerization domain-containing protein 1 and 2; P. acnes: Propionibacterium acnes; PAMPs: Pathogen-associated molecular patterns; PYD: Pyrin domain; RICK: Receptor-interacting protein-like interacting caspase-like apoptosis regulatory protein kinase; RIP: Receptor-interacting protein; TLRs: Toll-like receptors
}

Funding

Not applicable.

\section{Availability of data and materials}

Not applicable, since this is a review-type manuscript.

\section{Authors' contributions}

$N Y$ and $\Pi$ carried out the summarization and description of this manuscript. YS and YE contributed the sarcoidosis section. HT contributed the GVHD section. $\mathrm{RH}, \mathrm{YI}$, and $\mathrm{HS}$ contributed the malignant disease section. NY and MM contributed the Crohn's disease and Blau syndrome section. All authors read and approved the final manuscript.

\section{Ethics approval and consent to participate}

Not applicable, since this is a review-type manuscript.

\section{Consent for publication \\ Not applicable.}

\section{Competing interests}

The authors declare that they have no competing interests.

\section{Publisher's Note}

Springer Nature remains neutral with regard to jurisdictional claims in published maps and institutional affiliations.

\section{Author details}

${ }^{1}$ Department of Public Health and Preventive Medicine, Graduate School of Medicine, Yamaguchi University, 1-1-1 Minami-Kogushi, Ube, Yamaguchi 755-8505, Japan. Department of Human Pathology, Graduate School and Faculty of Medicine, Tokyo Medical and Dental University, Tokyo, Japan.

Received: 7 August 2017 Accepted: 28 September 2017

Published online: 11 October 2017

\section{References}

1. Dostert C, Pétrilli V, Van Bruggen R, Steele C, Mossman BT, Tschopp J. Innate immune activation through Nalp3 inflammasome sensing of asbestos and silica. Science. 2008;320:674-7.

2. Ogino K, Zhang R, Takahashi H, Takemoto K, Kubo M, Murakami I, Wang DH, Fujikura Y. Allergic airway inflammation by nasal inoculation of particulate matter (PM2.5) in NC/Nga mice. PLoS One. 2014;9(3):e92710.

3. Kawai T, Akira S. Innate immune recognition of viral infection. Nat Immunol. 2006;7:131-7

4. Inohara A, Chamaillard M, McDonald C, Nuñez G. NOD-LRR proteins: role in host-microbial interactions and inflammatory disease. Annu Rev Biochem. 2005;74:355-83

5. Inohara N, Ogura Y, Chen FF, Muto A, Nuñez G. Human Nod1 confers responsiveness to bacterial lipopolysaccharides. J Biol Chem. 2001;276: 2551-4.

6. Chamaillard M, Hashimoto M, Horie Y, Masumoto J, Qiu S, Saab L, Ogura Y, Kawasaki A, Fukase K, Kusumoto S, Valvano MA, Foster SJ, Mak TW, Nuñez G, Inohara N. An essential role for NOD1 in host recognition of bacterial peptidoglycan containing diaminopimelic acid. Nat Immunol. 2003;4:702-7.

7. Inohara N, Ogura Y, Fontalba A, Gutierrez O, Pons F, Crespo J, Fukase K, Inamura S, Kusumoto S, Hashimoto M, Foster SJ, Moran AP, Fernandez-Luna $J$, Nuñez G. Host recognition of bacterial muramyl dipeptide mediated through NOD2. Implications for Crohn's disease. J Biol Chem. 2003;278: 5509-12.

8. Inohara N, Koseki T, Lin J, del Peso L, Lucas PC, Chen FF, Ogura Y, Núñez G. An induced proximity model for NF-kappa B activation in the Nod1/RICK and RIP signaling pathways. J Biol Chem. 2000;275:27823-31.

9. Masumoto J, Yang K, Varambally S, Hasegawa M, Tomlins SA, Qiu S, Fujimoto Y, Kawasaki A, Foster SJ, Horie Y, Mak TW, Núñez G, Chinnaiyan AM, Fukase K, Inohara N. Nod1 acts as an intracellular receptor to stimulate chemokine production and neutrophil recruitment in vivo. J Exp Med. 2006; 203(1):203-13

10. Bonen DK, Ogura Y, Nicolae DL, Inohara N, Saab L, Tanabe T, Chen FF, Foster SJ, Duerr RH, Brant SR, Cho JH, Nuñez G. Crohn's disease-associated NOD2 variants share a signaling defect in response to lipopolysaccharide and peptidoglycan. Gastroenterology. 2003;124:140-1406. 
11. Yamazaki K, Takazoe M, Tanaka T, Kazumori T, Nakamura Y. Absence of mutation in the NOD2/CARD15 gene among 483 Japanese patients with Crohn's disease. J Hum Genet. 2002;47(9):469-72.

12. Leong RW, Armuzzi A, Ahmad T, Wong ML, Tse P, Jewell DP, Sung JJ. NOD2/CARD15 gene polymorphisms and Crohn's disease in the Chinese population. Aliment Pharmacol Ther. 2003:17:1465-70.

13. Croucher PJ, Mascheretti S, Hampe J, Huse K, Frenzel H, Stoll M, Lu T, Nikolaus S, Yang SK, Krawczak M, Kim WH, Schreiber S. Haplotype structure and association to Crohn's disease of CARD15 mutations in two ethnically divergent populations. Eur J Hum Genet. 2003;11:6-16.

14. Sugimura M, Kinouchi Y, Takahashi S, Aihara H, Takagi S, Negoro K, Obana N, Kojima Y, Matsumoto K, Kikuchi T, Hiroki M, Oomori S, Shimosegawa T. CARD15/NOD2 mutational analysis in Japanese patients with Crohn's disease. Clin Genet. 2003;63(2):160-2.

15. Kobayashi KS, Chamaillard M, Ogura Y, Henegariu O, Inohara N, Nuñez G, Flavell RA. Nod2-dependent regulation of innate and adaptive immunity in the intestinal tract. Science. 2005:307:731-4

16. Jabs DA, Houk JL, Bias WB, Arnett FC. Familial granulomatous synovitis, uveitis, and cranial neuropathies. Am J Med. 1985;78:801-4.

17. Miceli-Richard C, Lesage S, Rybojad M, Prieur AM, Manouvrier-Hanu S, Häfner R, Chamaillard M, Zouali H, Thomas G, Hugot JP. CARD15 mutations in Blau syndrome. Nat Genet. 2001;29:19-20.

18. Tanabe T, Chamaillard M, Ogura Y, Zhu L, Qiu S, Masumoto J, Ghosh P, Moran A, Predergast MM, Tromp G, Williams CJ, Inohara N, Núñez G. Regulatory regions and critical residues of NOD2 involved in muramyl dipeptide recognition. EMBO J. 2004;23:1587-97.

19. Okafuji I, Nishikomori R, Kanazawa N, Kambe N, Fujisawa A, Yamazaki S, Saito M, Yoshioka T, Kawai T, Sakai H, Tanizaki H, Heike T, Miyachi Y, Nakahata T. Role of the NOD2 genotype in the clinical phenotype of Blau syndrome and early-onset sarcoidosis. Arthritis Rheum. 2009;60:242-50.

20. Ishige I, Usui Y, Takemura T, Eishi Y. Quantitative PCR of mycobacterial and propionibacterial DNA in lymph nodes of Japanese patients with sarcoidosis. Lancet. 1999;354:120-3.

21. Akahoshi M, Ishihara M, Namba K, Kitaichi N, Ando Y, Takenaka S, Ishida T, Ohno S, Mizuki N, Nakashima H, Shirakawa T. Mutation screening of the CARD15 gene in sarcoidosis. Tissue Antigens. 2008;71(6):564-7.

22. Schurmann M, Valentonyte R, Hampe J, Muller-Quernheim J, Schwinger E, Schreiber S. CARD15 gene mutations in sarcoidosis. Eur Respir J. 2003;22: 748-54.

23. Tanabe $T$, Ishige I, Suzuki $Y$, Aita $Y$, Furukawa A, Ishige $Y$, Uchida $K$, Suzuki $T$, Takemura T, Ikushima S, Oritsu M, Yokoyama T, Fujimoto Y, Fukase K, Inohara N, Nunez G, Eishi Y. Sarcoidosis and NOD1 variation with impaired recognition of intracellular Propionibacterium acnes. Biochim Biophys Acta. 2006;1762(9):794-801.

24. Rosenstiel P, Hellmig S, Hampe J, Ott S, Till A, Fischbach W, Sahly H, Lucius $R$, Foelsch UR, Philpott D, Schreiber S. Influence of polymorphisms in the NOD1/CARD4 and NOD2/CARD15 genes on the clinical outcome of $\mathrm{H}$. pylori infection. Cell Microbiol. 2006;8:1188-98.

25. Kurzawski G, Suchy J, Kladny J, Grabowska E, Mierzejewski M, Jakubowska A, Debniak T, Cybulski C, Kowalska E, Szych Z, Domagala W, Scott RJ, Lubinski J. The NOD2 3020insC mutation and the risk of colorectal cancer. Cancer Res. 2004;64:1604-6.

26. Lener MR, Oszutowska D, Castaneda J, Kurzawski G, Suchy J, Nej-Wołosiak K, Byrski T, Huzarski T, Gronwald J, Szymańska A, Szymańska-Pasternak J, Grodzki T, Serwatowski P, Bre Borowicz G, Scott RJ, Lubiński J. Prevalence of the NOD2 3020insC mutation in aggregations of breast and lung cancer. Breast Cancer Res Treat. 2006;95:141-5.

27. Tanabe T, Yamaguchi N, Matsuda K, Yamazaki K, Takahashi S, Tojo A, Onizuka M, Eishi Y, Akiyama H, Ishikawa J, Mori T, Hara M, Koike K, Kawa K, Kawase T, Morishima Y, Amano H, Kobayashi-Miura M, Kakamu T, Nakamura Y, Asano S, Fujita Y. Association analysis of the NOD2 gene with susceptibility to graft-versus-host disease in a Japanese population. Int J Hematol. 2011;93:771-8.

28. Sioud M, Fløisand Y. NOD2/CARD15 on bone marrow CD34+ hematopoietic cells mediates induction of cytokines and cell differentiation. J Leukoc Biol. 2009;85(6):939-46

29. Karin $M$, Lawrence $T$, Nizet $V$. Innate immunity gone awry: linking microbial infections to chronic inflammation and cancer. Cell. 2006;124: 823-35.

30. van Beelen AJ, Zelinkova Z, Taanman-Kueter EW, Muller FJ, Hommes DW, Zaat SA, Kapsenberg ML, de Jong EC. Stimulation of the intracellular bacterial sensor NOD2 programs dendritic cells to promote interleukin-17 production in human memory T cells. Immunity. 2007;27:660-9.

31. Holler E, Rogler G, Herfarth H, Brenmoehl J, Wild PJ, Hahn J, Eissner G, Schölmerich J, Andreesen R. Both donor and recipient NOD2/ CARD15 mutations associate with transplant-related mortality and GvHD following allogeneic stem cell transplantation. Blood. 2004;104: 889-94.

32. Holler E, Rogler G, Brenmoehl J, Hahn J, Herfarth H, Greinix H, Dickinson AM, Socié G, Wolff D, Fischer G, Jackson G, Rocha V, Steiner B, Eissner G, Marienhagen J, Schoelmerich J, Andreesen R. Prognostic significance of NOD2/CARD15 variants in HLA-identical sibling hematopoietic stem cell transplantation: effect on long-term outcome is confirmed in 2 independent cohorts and may be modulated by the type of gastrointestinal decontamination. Blood. 2006;107:4189-93.

33. Granell M, Urbano-Ispizua A, Aróstegui Jl, Fernández-Avilés F, Martínez C, Rovira M, Rius J, Plaza S, Gaya A, Navarro A, Talarn C, Carreras E, Monzó M, Montserrat E, Yagüe J. Effect of NOD2/CARD15 variants in T-cell depleted allogeneic stem cell transplantation. Haematologica. 2006;91:1372-6.

34. Oh H, Loberiza FR Jr, Zhang MJ, Ringdén O, Akiyama H, Asai T, Miyawaki S, Okamoto S, Horowitz MM, Antin JH, Bashey A, Bird JM, Carabasi MH, Fay JW Gale RP, Giller RH, Goldman JM, Hale GA, Harris RE, Henslee-Downey J, Kolb HJ, Litzow MR, McCarthy PL, Neudorf SM, Serna DS, Socié G, Tiberghien P Barrett AJ. Comparison of graft-vs-host disease and survival after HLAidentical sibling bone marrow transplantation in ethnic populations. Blood. 2005;105:1408-16.

\section{Submit your next manuscript to BioMed Central and we will help you at every step:}

- We accept pre-submission inquiries

- Our selector tool helps you to find the most relevant journal

- We provide round the clock customer support

- Convenient online submission

- Thorough peer review

- Inclusion in PubMed and all major indexing services

- Maximum visibility for your research

Submit your manuscript at www.biomedcentral.com/submit
BioMed Central 